\title{
Economic route to sodium-containing silicate bioactive glass scaffold
}

\author{
Enobong R. Essien ${ }^{1}$, Luqman A. Adams ${ }^{2 *}$, Rafiu O. Shaibu ${ }^{2}$, Idris A. Olasupo ${ }^{2}$, Aderemi Oki $^{3}$ \\ ${ }^{1}$ Department of Chemical Sciences, Bells University of Technology, Ota, Nigeria \\ ${ }^{2}$ Department of Chemistry, Faculty of Science, University of Lagos, Lagos, Nigeria; ${ }^{*}$ Corresponding Author: ladams@unilag.edu.ng \\ ${ }^{3}$ Department of Chemistry, Prairie View A \& M University, Prairie View, USA
}

Received 10 October 2012; revised 19 November 2012; accepted 7 December 2012

\begin{abstract}
Tetraethyl orthosilicate (TEOS) and trimethyl orthosilicate (TMOS) alkoxysilanes are expensive common precursors for silicate-based solgelderived bioactive glasses. Facile approaches involving low cost substitutes are a necessity for bioactive glass implants in bone regeneration therapy. Quaternary $\mathrm{SiO}_{2}-\mathrm{Na}_{2} \mathrm{O}-\mathrm{CaO}-\mathrm{P}_{2} \mathrm{O}_{5}$ bioactive glass was prepared by the sol-gel method from locally sourced sand as precursor. The monolith glass material obtained was subjected to immersion studies in simulated body fluid (SBF) for 21 days. The surface morphology and composition of the glass before and after immersion in SBF was studied using SEM-EDX, while $\mathrm{pH}$ analysis was used to monitor changes on the glass surface in SBF solution. FTIR was used to confirm apatite formation on the material. Results showed that the concentration of $\mathrm{Ca}$, $P$ and $C$ increased on the surface of the glass sample as immersion time increased, which was attributed to the formation of carbonated hydroxyapatite (HCA). The material shows ability to bond to bone making it a promising scaffold material for bone repair.
\end{abstract}

Keywords: Sand; Alkoxysilanes; Carbonated Hydroxyapatite; Simulated Body Fluid; Bone Regeneration

\section{INTRODUCTION}

Bioactive glasses are increasingly being utilised as implants for bone tissue repair because of their ability to form strong interfacial bonding with bone when in contact with physiological fluids [1,2]. The formation of hydroxyl carbonated apatite (HCA) layer, the mineral phase of bone on the glass surface provides direct bonding between the host tissue and the implant material [3]. Bioactive glasses have been used in few clinical applica- tions; ossicular implantation to alleviate conductive hearing loss, dental implants to maintain endosseous ridge, and to augment the natural repair process in patients with periodontal disease [4].

45S5 Bioglass ${ }^{\circledR}$ with composition (in wt\%) $45 \mathrm{SiO}_{2}$, $24.5 \mathrm{CaO}, 24.5 \mathrm{Na}_{2} \mathrm{O}$ and $6 \mathrm{P}_{2} \mathrm{O}_{5}$ remains at the fore, capable of bonding to both soft and hard tissues [1]. The mechanism of bonding to living tissue involves a sequence of reaction steps [4]. The first 5 steps are reactions occurring on the glass surface that entail rapid ion exchange of $\mathrm{Na}^{+}$with $\mathrm{H}^{+}$and $\mathrm{H}_{3} \mathrm{O}^{+}$followed by dissolution of the glass network, polycondensation reaction of surface silanols $(\mathrm{Si}-\mathrm{OH})$ to high surface area silica $\left(\mathrm{SiO}_{2}\right)$ gel. In the second phase, the growing HCA layer on the surface of the glass acts as an ideal environment for the subsequent 6 cellular reaction steps during which osteoblasts (stem cells) differentiate to form new bone and bond to the implant surface [4].

The application of bioactive glasses as load-bearing implants is limited due to their poor mechanical integrity. In this regard, inclusion of sodium in the glass network during the preparation and subsequent thermal treatment has as a major advantage of enhancing its mechanical properties through the formation of $\mathrm{Na}_{2} \mathrm{Ca}_{2} \mathrm{Si}_{3} \mathrm{O}_{9}$ crystalline phase [5-7]. One of the concerns associated with crystallization is the possibility of affecting the biodegradability of the scaffold, an essential feature of tissue engineering scaffolds. However, crystalline $\mathrm{Na}_{2} \mathrm{Ca}_{2} \mathrm{Si}_{3} \mathrm{O}_{9}$ formed in 45S5 Bioglass ${ }^{\circledR}$ during sintering transforms to a degradable amorphous calcium phosphate when the scaffold is incubated in an aqueous solution similar to biological fluids [8]. Another important advantage is that inclusion of $\mathrm{Na}$ coupled with the high specific surface area of sol-gel-derived bioactive glasses [9] could lead to higher dissolution rates of the final materials in aqueous media as an important factor for the interaction of the material with living tissues $[10,11]$.

Alkoxysilanes, TEOS and TMOS used in sol-gel synthesis are not only expensive, but also toxic on inhalation, Nayak et al. [12], Crisan et al. [13], Li et al. [14] and 
Pabon et al. [15]. Apart from the ease of generation of $\mathrm{SiO}_{2}$ during the processes of hydrolysis and condensation of these precursors, no other oxide is formed as sideproduct. Consequently, the composition of the bioactive glass may be easily adjusted during preparation.

Nayak et al. [16] prepared bioglass-ceramics in the $\mathrm{SiO}_{2}-\mathrm{Na}_{2} \mathrm{O}-\mathrm{CaO}$ system using rice hull ash (RHA). In continuation of our interest in the synthesis of bioactive glass scaffolds suitable for bone tissue repair, we report herein the preparation of bioactive glass in the quarternary system containing $\mathrm{SiO}_{2}-\mathrm{CaO}-\mathrm{Na}_{2} \mathrm{O}-\mathrm{P}_{2} \mathrm{O}_{5}$ from inexpensive and readily available silica-rich Nigerian sand as precursor via the sol-gel process.

\section{MATERIALS AND METHODS}

\subsection{Materials}

The sand used as starting material was obtained from Ifo in Ogun State, South-West Nigeria and had the composition shown in Table 1. Analytical grade reagents were used as obtained to include; $\mathrm{Ca}\left(\mathrm{NO}_{3}\right)_{2} \cdot 4 \mathrm{H}_{2} \mathrm{O}$ (Loba Chemicals, 98\%), $\mathrm{NaH}_{2} \mathrm{PO}_{4} \cdot 2 \mathrm{H}_{2} \mathrm{O}$ (Kermel, 99\%) and $\mathrm{HNO}_{3}$ (Riedel-deHaen, $60 \%$ ) to synthesize the bioactive glass.

\subsection{Preparation of Sodium Metasilicate from Sand}

The sand ranging from 159 - $595 \mu \mathrm{m}$ obtained after passing through sieves was washed thoroughly to free it from clay and other impurities and then oven-dried at $120^{\circ} \mathrm{C}$. Soda ash was mixed thoroughly with the sand at a ratio of $\mathrm{Na}_{2} \mathrm{O}: \mathrm{SiO}_{2}$ of $1: 2$ in the final product. The mixture was then placed in a cavity constructed with bricks and fused in a furnace at $1300^{\circ} \mathrm{C}$ for 1 hour to form sodium metasilicate.

\subsection{Preparation of Bioactive Glass}

General procedure for bioactive glass with composition (wt\%) $30.55 \mathrm{SiO}_{2}, 28.57 \mathrm{Na}_{2} \mathrm{O}, 33.21 \mathrm{CaO}$ and 7.67

Table 1. Composition of the sand.

\begin{tabular}{cc}
\hline Element & $(\%)$ mass \\
\hline $\mathrm{SiO}_{2}$ & 98 \\
$\mathrm{Fe}_{2} \mathrm{O}_{3}$ & 0.97 \\
$\mathrm{MgO}$ & 0.046 \\
$\mathrm{Al}_{2} \mathrm{O}_{3}$ & 0.53 \\
$\mathrm{~K}_{2} \mathrm{O}$ & 0.35 \\
$\mathrm{Na}_{2} \mathrm{O}$ & 0.043 \\
$\mathrm{CaO}$ & 0.061
\end{tabular}

$\mathrm{P}_{2} \mathrm{O}_{5}$ is a modification of Chen et al.'s method of synthesizing sol-gel Bioglass ${ }^{\circledR} 45 \mathrm{~S} 5$ [17]. The sodium metasilicate was added slowly to $0.05 \mathrm{M} \mathrm{HNO}_{3}$ under stirring condition with a magnetic stirrer for 1 hour to facilitate complete hydrolysis. Thereafter, $\mathrm{NaH}_{2} \mathrm{PO}_{4} \cdot 2 \mathrm{H}_{2} \mathrm{O}$ and $\mathrm{Ca}\left(\mathrm{NO}_{3}\right)_{2} \cdot 4 \mathrm{H}_{2} \mathrm{O}$ were added slowly in a molar ratio of 1:20 of water in sequence while stirring for 45 minutes each. After the final addition, the mixture was stirred for additional 1 hour before pouring the resulting sol into teflon moulds and kept at room temperature for 72 hour for gelation. The obtained gel was heated at $70^{\circ} \mathrm{C}$ for 72 hours, $130^{\circ} \mathrm{C}$ for 42 hours, $700^{\circ} \mathrm{C}$ for 2 hours and $950^{\circ} \mathrm{C}$ for 3 hours for aging, drying, stabilization and sintering respectively. The heating and cooling rate was maintained at $5^{\circ} \mathrm{C} / \mathrm{min}$.

\subsection{Characterization}

The density $p_{\text {glass }}$ of the bioactive glass was determined from the mass and dimensions of the sintered body. The porosity $P$ was calculated by

$$
P=\left(1-p_{\text {glass }} / p_{\text {solid }}\right) \times 100
$$

where $p_{\text {solid }}=2.7 \mathrm{~g} / \mathrm{cm}^{3}$ is the density of solid $45 \mathrm{~S} 5$

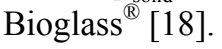

The microstructure of the glass was characterized in a EVO/MAIO scanning electron microscope (SEM) equipped with energy dispersive X-ray analyzer (EDX) before and after immersion in simulated body fluid (SBF) for maximum of 21 days. The sample was carbon-coated and observed at an accelerating voltage of $15 \mathrm{kV}$. Fourier transform infrared (FTIR, Shimadzu 8400 S), with wavenumber range of $4000-400 \mathrm{~cm}^{-1}$, employing $\mathrm{KBr}$ pellets operating in a reflectance mode with a $4 \mathrm{~cm}^{-1}$ resolution was used to monitor the nature of bonds present in the glass network.

\subsection{Bioactivity Test}

Assessment of bioactivity was carried out using the standard in vitro procedure described by Kokubo et al. [19] using analytical reagent-grade chemicals $\mathrm{NaCl}$, $\mathrm{NaHCO}_{3}, \mathrm{KCl}, \mathrm{K}_{2} \mathrm{HPO}_{4} \cdot 3 \mathrm{H}_{2} \mathrm{O}, \mathrm{MgCl}_{2} \cdot 6 \mathrm{H}_{2} \mathrm{O}, \mathrm{CaCl}_{2}$, trishydroxymethyl aminomethane [Tris-buffer,

$\left.\left(\mathrm{CH}_{2} \mathrm{OH}\right)_{3} \mathrm{CNH}_{2}\right]$, and $1 \mathrm{M} \mathrm{HCl}$ with ions concentrations shown in Table 2 Samples were immersed in acellular SBF at concentration of $0.01 \mathrm{~g} / \mathrm{ml}$ [20] in clean plastic bottles, which had previously been washed using $\mathrm{HCl}$ and deionized water. The bottles were placed inside an incubator at a controlled temperature of $36.5^{\circ} \mathrm{C}$ and $\mathrm{pH}$ was maintained at 7.4. The SBF solutions were not refreshed throughout the period of immersion. The $\mathrm{pH}$ of the solution was checked daily for 9 days using a $\mathrm{pH}$ meter. The samples were extracted from the SBF solution after given times of 7,14 and 21 days, 
Table 2. Ion concentrations (mM) in human plasma in comparison with SBF [31].

\begin{tabular}{ccc}
\hline Ion & SBF & Human Plasma \\
\hline $\mathrm{Na}^{+}$ & 142.0 & 142.0 \\
$\mathrm{~K}^{+}$ & 5.0 & 5.0 \\
$\mathrm{Mg}^{2+}$ & 1.5 & 1.5 \\
$\mathrm{Ca}^{2+}$ & 2.5 & 2.5 \\
$\mathrm{Cl}^{-}$ & 147.8 & 103.0 \\
$\mathrm{HCO}_{3}^{-}$ & 4.2 & 27.0 \\
$\mathrm{HPO}_{4}^{2-}$ & 1.0 & 1.0 \\
$\mathrm{SO}_{4}^{2-}$ & 0.5 & 0.5 \\
\hline
\end{tabular}

rinsed with deionized water and left to dry at ambient temperature in a desiccator. The formation of apatite layer on the glass surface was monitored by SEM/EDX and FTIR.

\section{RESULTS AND DISCUSSION}

\subsection{Densification, Bulk Density and Porosity}

The density of the as-sintered glass was $0.4944 \mathrm{~g} / \mathrm{cm}^{3}$ while it's porosity obtained by applying Eq.1 was $82 \%$, indicating that only partial densification occurred after heating the glass at $950^{\circ} \mathrm{C}$ for $3 \mathrm{~h}$. This result is quantitatively similar to those obtained by Chen et al. [6] who showed that complete densification of Bioglass ${ }^{\mathbb{B}}$ construct may be obtained after sintering above $950^{\circ} \mathrm{C}$. Extensive densification leads to hardening of a material by strengthening the pore struts and overall reduction in porosity. Significant densification of the glass can lead to full crystallization which can transform a bioactive glass into an inert material [6]. For this reason, the material should be sintered at a temperature at which crystallization does not occur to a great extent to maintain bioactivity. However, insufficient densification may occur by sintering at low temperature which can lead to a very fragile scaffold containing loosely packed particles. The result also shows that the glass is highly porous, an ideal criterion for tissue engineering scaffold which facilitates cell seeding and infiltration, tissue in growth and vascularization, as well as nutrient delivery and removal [21].

\subsection{SEM/EDX Observation of Bioactive Glass before and after Immersion in SBF}

In Figure 1, the SEM micrograph of the glass after sintering at $950^{\circ} \mathrm{C}$ is shown. The EDX confirms the presence of $\mathrm{Si}, \mathrm{Na}, \mathrm{Ca}$ and $\mathrm{P}$ in the glass sample as prepared. The presence of Al may be due to impurity in the sample. The material shows heterogeneous surfaces of flaky particles with few crystalline portions and some voids distributed to give a porous structure. After seven days of immersion in SBF, agglomerated balls of hydroxyapatite (HA) is observed growing out of the surface (Figure 2(a)). The composition of the surface as shown by EDX indicates that the concentration of sodium in the bioactive glass decreases in agreement with the dissolution theory of bioactive glasses in physiological fluids $[22,23]$. The increase in concentration of $\mathrm{Ca}$ and $\mathrm{P}$ in the material is due to the formation of HA on the surface of the material $[5,24,25]$.

After 14 days in SBF solution, the HA particles were coarser and heavily agglomerated to develop a dune-like shape shown in Figure 2(b). Smaller particles can be seen growing out from the coarser apatite layer. This appearance may be due to the formation of crystalline HCA by incorporation of $\mathrm{CO}_{3}^{2-}$ from the SBF solution onto the glass surface. The apatite layer became flaky and aggregated and had almost completely covered the surface of the glass after 21 days leading to a low detection of Si by EDX, Figure 2(c). Chen and Thouas [26] have previously obtained similar results from sol-gel fabricated 45S5 Bioglass ${ }^{\circledR}$.

Figure 3 shows the HCA layers deposited on the surface of the glass which supports previous studies [27-29]. Formation of the apatite layer on a glass surface through biomineralization is thought an essential step for a glass to bond to living tissue in vivo [30].

\section{3. $\mathrm{pH}$ Changes during Immersion in SBF}

Changes in $\mathrm{pH}$ of the SBF solution after immersing the bioactive glass for the first 9 days is shown in Figure 4. The $\mathrm{pH}$ of the solution increased sharply for the first two days reaching a value of 8.4 compared with the initial $\mathrm{pH}$ of 7.4, thereafter it remains constant until the 4th day. This is due to the fast release of $\mathrm{Na}^{+}$and $\mathrm{Ca}^{2+}$ ions into the surrounding solution through exchange with $\mathrm{H}^{+}$ or $\mathrm{H}_{3} \mathrm{O}^{+}$ions [32]. The $\mathrm{H}^{+}$ions being replaced by cations, result in increase in hydroxyl concentration of the solution enabling formation of the silica glass network at the glass solution interface and attendant decrease in the $\mathrm{pH}$. After day 4 , the $\mathrm{pH}$ increases more gradually because part of the released calcium is used to form $\mathrm{CaO}-\mathrm{P}_{2} \mathrm{O}_{5^{-}}$ rich film, decreasing the $\mathrm{Ca}$ release kinetics. With prolonged immersion, the $\mathrm{pH}$ reached a saturated state $(\mathrm{pH}=$ 8.7). The $\mathrm{pH}$ variation of the bioactive glass is in agreement with previous studies on $\mathrm{pH}$ changes of gel-derived $\mathrm{SiO}_{2}-\mathrm{CaO}-\mathrm{Na}_{2} \mathrm{O}-\mathrm{P}_{2} \mathrm{O}_{5}$ bioactive glass in biological fluids [20].

\subsection{FTIR Evaluation of Bioactivity of the Glass}

The FTIR spectra of the glass samples soaked in SBF 


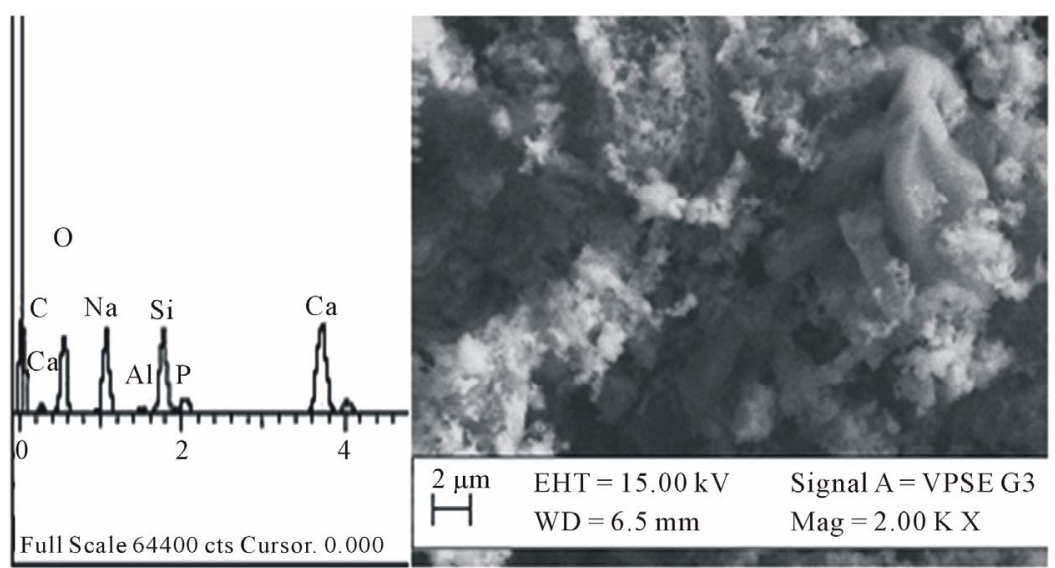

Figure 1. EDX spectrum and SEM micrograph of the bioactive glass as sintered.

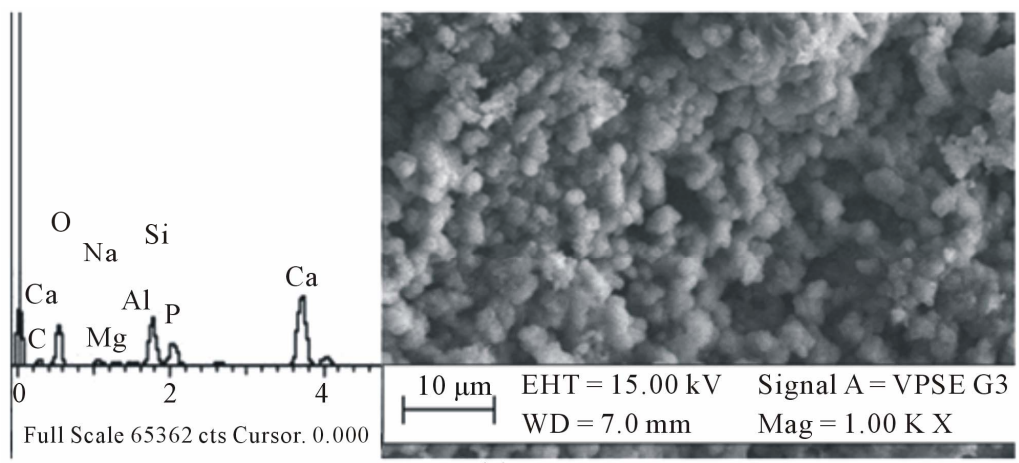

(a)

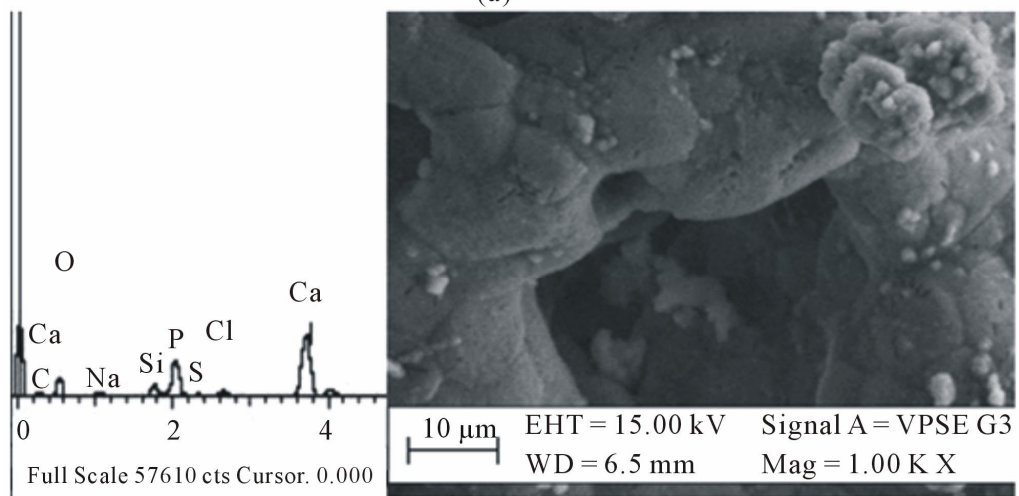

(b)

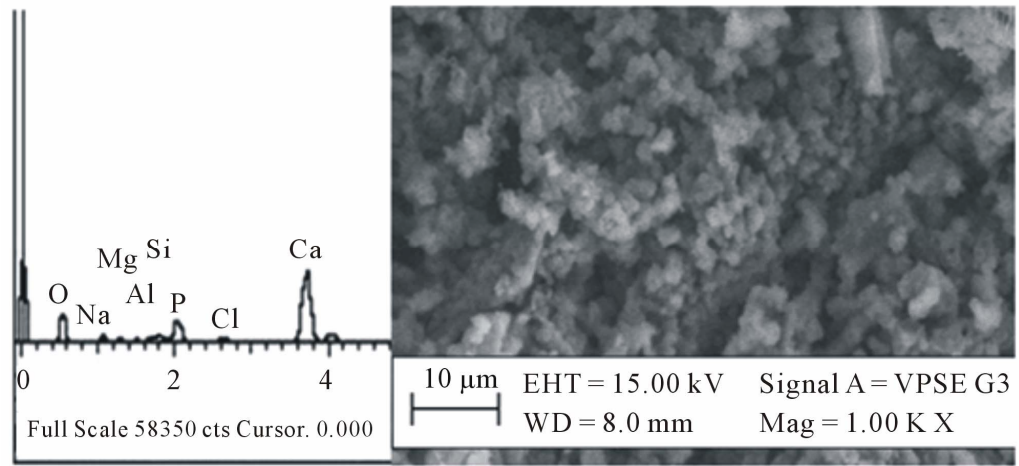

(c)

Figure 2. EDX spectra and SEM micrographs of the bioactive glass after immersion in SBF for (a) 7, (b) 14 and (c) 21 days showing the growth of apatite. 


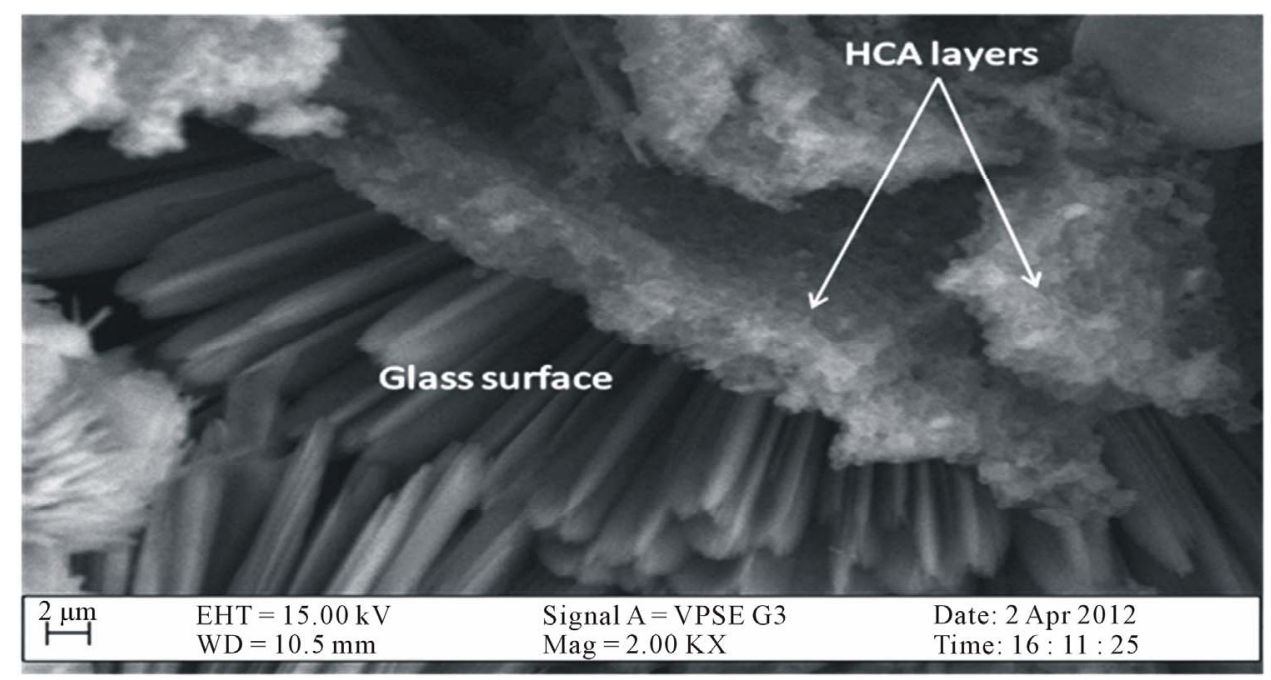

Figure 3. Cross-section of HCA layers precipitated on the surface of the bioactive glass.

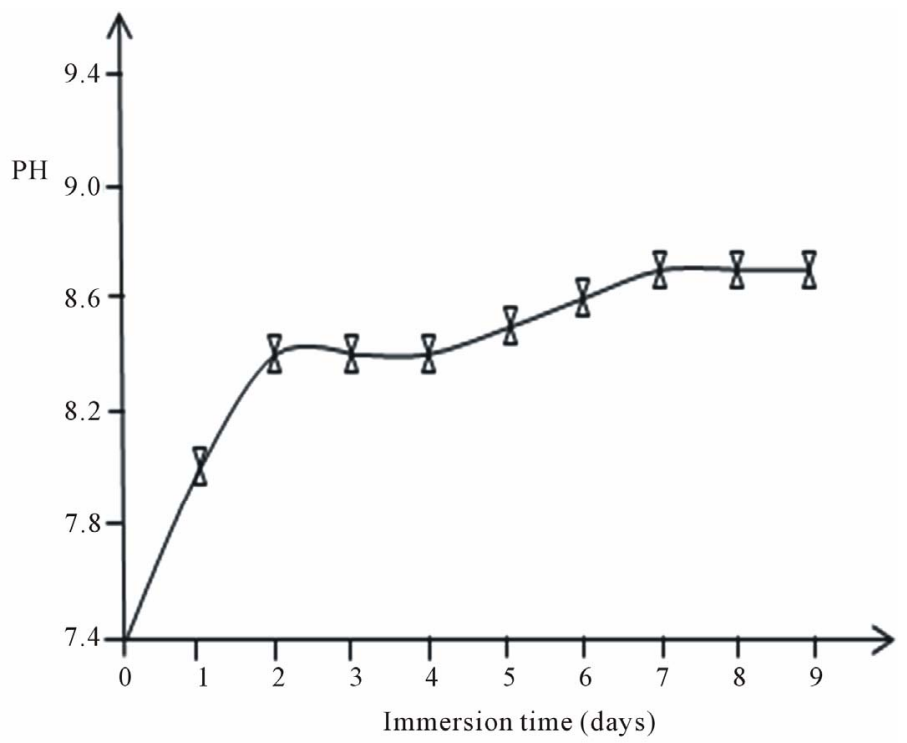

Figure 4. Days of bioactive glass immersion in $\mathrm{SBF}$ with $\mathrm{pH}$ from the initial $\mathrm{pH}=7.4$.

for $0,7,14$ and 21 days are shown in Figure 5. As observed, the spectrum of the parent glass before immersion reveals bands at $3424 \mathrm{~cm}^{-1}, 1641 \mathrm{~cm}^{-1}, 1119 \mathrm{~cm}^{-1}$, $1038 \mathrm{~cm}^{-1}, 964 \mathrm{~cm}^{-1}, 930 \mathrm{~cm}^{-1}, 901 \mathrm{~cm}^{-1}, 797 \mathrm{~cm}^{-1}, 681$ $\mathrm{cm}^{-1}, 641 \mathrm{~cm}^{-1}, 617 \mathrm{~cm}^{-1}, 567 \mathrm{~cm}^{-1}, 511 \mathrm{~cm}^{-1}$ and 475 $\mathrm{cm}^{-1}$. The band centred at $3424 \mathrm{~cm}^{-1}$ is attributed to $\mathrm{OH}^{-}$ absorption while $1641 \mathrm{~cm}^{-1}$ is a weak water absorbed band [31]. The bands at $1119 \mathrm{~cm}^{-1}$ and $1038 \mathrm{~cm}^{-1}$ are associated with $\mathrm{Si}-\mathrm{O}-\mathrm{Si}$ and $\mathrm{P}-\mathrm{O}$ vibrational modes [20,33]; $964-900 \mathrm{~cm}^{-1}$ are related to Si-O non-bridging oxygen bonds (NBO). The bands at 797 and $475 \mathrm{~cm}^{-1}$ are associated with $\mathrm{Si}-\mathrm{O}-\mathrm{Si}$ bending vibrations. The peak at $641 \mathrm{~cm}^{-1}$ and $617 \mathrm{~cm}^{-1}$ can be assigned to the presence of crystalline phase in the sample [17,34]. After soaking for 7 days only two bands appear in the region 1100 $900 \mathrm{~cm}^{-1}$; a sharp band at $1082 \mathrm{~cm}^{-1}$ and a shoulder at
$959 \mathrm{~cm}^{-1}$ suggesting the disruption of the NBO bonds due to leaching of $\mathrm{Ca}$ and dissolution of soluble silica at the glass interface during the period of immersion in SBF solution [4].

Several new peaks emerge at $1427 \mathrm{~cm}^{-1}$ and $872 \mathrm{~cm}^{-1}$, which can be attributed to the presence of $\mathrm{CO}_{3}^{2-}$ [35], and the peak at $573 \mathrm{~cm}^{-1}$ is assigned to $\mathrm{P}-\mathrm{O}$ bend in amorphous calcium phosphate. This suggests the onset of incorporation of $\mathrm{CO}_{3}^{2-}$ into HA. After 14 days of immersion, the bands between $1120-950 \mathrm{~cm}^{-1}$ increase in number which may be due to increased concentration of $\mathrm{Ca}^{2+}$ on the glass surface as a result of uptake from SBF solution. Additionally, the $\mathrm{CO}_{3}^{2-}$ band becomes broader and develops a second band at $1470 \mathrm{~cm}^{-1}$, while the peak at $573 \mathrm{~cm}^{-1}$ splits into two sharp modes at 604 and 554 $\mathrm{cm}^{-1}$, which are characteristic of apatite crystalline phase 


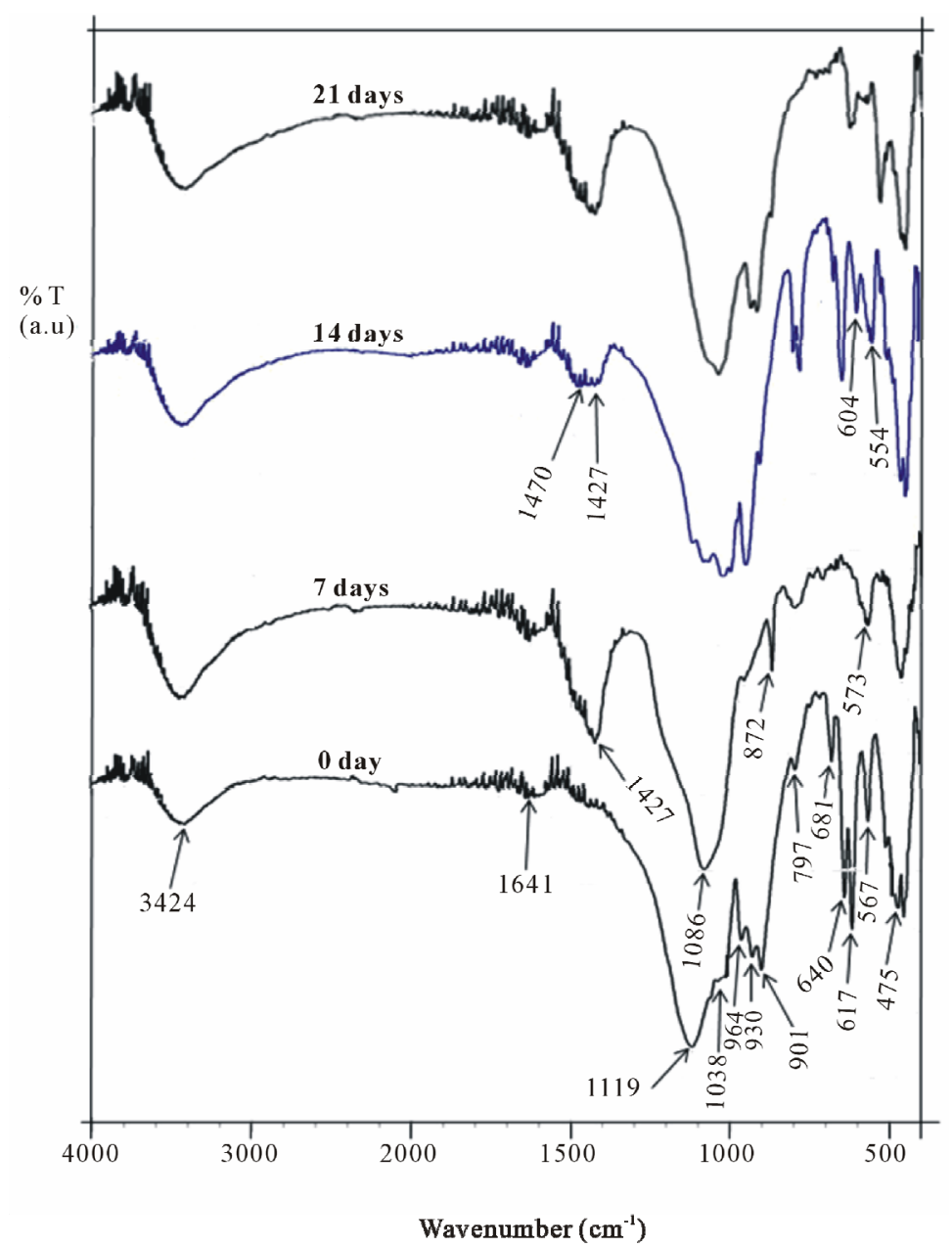

Figure 5. FTIR spectra of the glass soaked in SBF for 0 - 21 days.

[29] indicating that HCA now dominates the apatite phase as suggested earlier. As immersion days reached 21 days, the twin bands at $1470 \mathrm{~cm}^{-1}$ and $1427 \mathrm{~cm}^{-1}$ fuse into one and becomes more intense showing the precipitation of HCA on the glass surface.

\section{CONCLUSION}

A highly porous in vitro bioactive material composed of $\mathrm{SiO}_{2}-\mathrm{Na}_{2} \mathrm{O}-\mathrm{CaO}-\mathrm{P}_{2} \mathrm{O}_{5}$ has been prepared by the sol-gel technique from sand obtained from Ifo in Nigeria. The low cost precursor used and the low-temperature sol-gel processing is an appropriate method for preparation of a quaternary bioactive glass containing $\mathrm{Na}_{2} \mathrm{O}$. The sintering temperature of $950^{\circ} \mathrm{C}$ is optimal to provide a reasonable crystallinity, while maintaining good bioactivity and high resorbability in physiological fluids. Immersion study shows that the $\mathrm{pH}$ changes in SBF increased gradually to a value of 8.7 after 9 days, which allows us infer that the glass shows a controlled rate of degradation leading to HCA formation that may be useful in osteoconductivity. We therefore conclude that sand obtained from Ifo in Ogun State, South-West Nigeria could serve as a useful and viable low cost precursor for preparing large scale sodium-containing bioactive glasses with potentials for commercialization.

\section{ACKNOWLEDGEMENTS}

The authors thank sincerely staffers of the Central Research Laboratory of Bells University of Technology, Ota for their assistance and providing the facilities to carry out this work. We are also grateful to Sheda Science and Technology Complex (SHESTCO), Abuja for helping to run the EDX and SEM analysis on the samples.

\section{REFERENCES}

[1] Hench, L.L. (1991) Bioceramics, from concept to clinic. Journal of American Ceramic Society, 74, 1487-1510. doi:10.1111/j.1151-2916.1991.tb07132.x

[2] Hench, L.L. and LaTorre, G.P. (1993) The reaction kinetics of bioactive ceramics. Part IV. Effect of glass and solution composition. In: Yamamuro, Kokubo and Nakamura, Eds., Bioceramics, Kobunshi Kankokai Press, Kyoto, $67-74$. 
[3] Best, S.M., Porter, A.E., Thian, E.S. and Huang, J. (2008) Bioceramics: Past, present and for the future. Journal of the European Ceramic Society, 28, 1319-1327. doi:10.1016/i.jeurceramsoc.2007.12.001

[4] Gerhardt, L.C. and Boccaccini, A.R. (2010) Bioactive glass and glass-ceramic scaffolds for bone tissue engineering. Materials, 3, 3867-3910. doi: $10.3390 / \mathrm{ma3} 073867$

[5] Peitl, O., Zanotto, E.D. and Hench L.L. (2001) Highly bioactive $\mathrm{P}_{2} \mathrm{O}_{5}-\mathrm{Na}_{2} \mathrm{O}-\mathrm{CaO}-\mathrm{SiO}_{2}$ glass-ceramics. Journal of Non-Crystalline Solids, 292, 115-126. doi:10.1016/S0022-3093(01)00822-5

[6] Chen, Q., Thompson, I.D. and Boccaccini, A.R. (2006) 45S5 Bioglass ${ }^{\circledR}$-derived glass-ceramic scaffolds for bone tissue engineering. Biomaterials, 27, 2414-2425. doi:10.1016/j.biomaterials.2005.11.025

[7] Bahniuk, M.S., Pirayesh, H., Singh, H.D., Nychka, J.A. and Unsworth, L.D. (2012) Bioactive glass 45S5 powders: Effect of synthesis route and resultant surface chemistry and crystallinity on protein adsorption from human plasma. Biointerphases, 7, 41. doi:10.1007/s13758-012-0041-y

[8] Chen, Q.Z. and Boccaccini, A.R. (2006) Coupling mechanical competence and bioresorbability in Bioglass ${ }^{\circledR}$ derived tissue engineering scaffolds. Advanced Engineering Materials, 8, 285-289. doi:10.1002/adem.200500259

[9] Hench, L.L. (1998) Bioceramics. Journal of American Ceramic Society, 81, 1705-1728. doi:10.1111/j.1151-2916.1998.tb02540.x

[10] Jones, J.R., Gentleman, E. and Polak, J. (2007) Bioactive scaffolds for bone regeneration. Elements, 3, 393-399. doi:10.2113/GSELEMENTS.3.6.393

[11] Vallet-Regí, M., Rangel, V.R. and Salinas, A.J. (2003) The in vitro bioactivity of mesoporous bioactive bioactive glasses. European Journal of Inorganic Chemistry, 6, 1029-1042. doi:10.1002/ejic.200390134

[12] Nayak, J.P. and Bera, J. (2010) Effect of sintering temperature on mechanical behaviour and bioactivity of solgel synthesized bioglass-ceramics using rice husk ash as a silica source. Applied Surface Science, 257, 458-462. doi:10.1016/j.apsusc.2010.07.011

[13] Crisan, M., Raileanu, M., Preda, S., Zaharescu, M., Valean, A.M., Popovici, E.J., Teodorescu, V.S., Matejec, V. and Mrazek, J. (2006) Manganese doped sol-gel materials with catalytic properties. Journal of Optoelectronics and Advanced Materials, 8, 815-819.

[14] Li, Z., Hou, B., Xu, Y., Wu, D., Sun, Y., Hu, W. and Deng, F. (2005) Comparative study of sol-gel hydrothermal and sol-gel synthesis of titania-silica composite nanoparticles. Journal of Solid State Chemistry, 178, 1395-1405. doi:10.1016/j.jssc.2004.12.034

[15] Pabon, E., Retuert, J., Quijada, R. and Zarate, A. (2004) $\mathrm{TiO}_{2}-\mathrm{SiO}_{2}$ mixed oxides prepared by a combined sol-gel and polymer inclusion method. Microporous Materials, 67, 195-203. doi:10.1016/j.micromeso.2003.10.017

[16] Nayak, J.P., Kumar, S. and Bera, J. (2010) Sol-gel synthesis of bioglass-ceramics using rice husk ash as a source for silica and it characterization. Journal of NonCrystalline Solids, 356, 1447-1451.

doi:10.1016/j.jnoncrysol.2010.04.041

[17] Chen, Q.-Z., Yuan, L.Y., Jin, L.-Y., Quinn, J.M.W. and Komesaroff, P.A. (2010) A new sol-gel process for producing $\mathrm{Na}_{2} \mathrm{O}$-containing bioactive glass ceramics. Acta Biomaterialia, 6, 4143-4153. doi:10.1016/j.actbio.2010.04.022

[18] Hench, L.L. and Wilson, J. (1984) Surface-active biomaterials. Science, 226, 630-636. doi:10.1126/science.6093253

[19] Kokubo, T. and Takadama, H. (2006) How useful is SBF in predicting in vivo bone bioactivity? Biomaterials, 27, 2907-2915. doi:10.1016/j.biomaterials.2006.01.017

[20] Siqueira, R.L., Peitl, O. and Zanotto, E.D. (2011) GelDerived $\mathrm{SiO}_{2}-\mathrm{CaO}-\mathrm{Na}_{2} \mathrm{O}-\mathrm{P}_{2} \mathrm{O}_{5}$ bioactive powders: Synthesis and in vitro bioactivity. Materials Science and Engineering C, 31, 983-991. doi:10.1016/j.msec.2011.02.018

[21] Rezwan, K., Chen, Q.Z., Blaker, J.J. and Boccaccini, A.R. (2006) Biodegradable and bioactive porouspolymer/inorganic composite scaffolds for bone tissue engineering. Biomaterials, 27, 3413-3431. doi:10.1016/j.biomaterials.2006.01.039

[22] Cao, W. and Hench, L.L. (1996) Bioactive materials. Ceramics International, 22, 493-507. doi:10.1016/0272-8842(95)00126-3

[23] Hench, L.L., Splinter, R.J., Allen, W.C. and Greenlee Jr, T.K. (1971) Bonding mechanisms at the interface of ceramic prosthetic materials. Journal of Biomedical Materials Research, 2, 117-141. doi:10.1002/jbm.820050611

[24] Kokubo, T., Kim, H.-M. and Kawashita, M. (2003) Novel bioactive materials with different mechanical properties. Biomaterials, 24, 2161-2175. doi:10.1016/S0142-9612(03)00044-9

[25] Li, P., de Groot, K. and Kokubo, T. (1996) Bioactive $\mathrm{Ca}_{10}\left(\mathrm{PO}_{4}\right)_{6}(\mathrm{OH})_{2}-\mathrm{TiO}_{2}$ composite coating prepared by sol-gel. Journal of Sol-Gel Science and Technology, 7, 27-33. doi:10.1007/BF00401880

[26] Chen, Q.-Z. and Thouas, G.A. (2011) Fabrication and characterization of sol-gel derived 45S5 Bioglass ${ }^{\circledR}$-ceramic scaffolds. Acta Biomaterialia, 7, 3616-3626. doi:10.1016/j.actbio.2011.06.005

[27] Kokubo, T., Ito, S., Huang, T., Hayashi, T., Sakka, S., Kitsugi, T., et al. (1990) Ca, P-rich layer formed on high strength bioactive glass-ceramic A-W. Journal of Biomedical Materials Research, 24, 331-343. doi: $10.1002 / \mathrm{jbm} .820240306$

[28] Vallet-Regí, M., Pérez-Pariente, M., Izquierdo-Barba, I. and Salinas, A. (2000) Compositional variations in the calcium phosphate layer growth on gel glasses soaked in a simulated body fluid. Chemical Materials, 12, 37703775. doi: $10.1021 / \mathrm{cm} 001068 \mathrm{~g}$

[29] Oliveira, J.M., Correia, R.N. and Fernandes, M.H. (2002) Effects of $\mathrm{Si}$ speciation on the in vitro bioactivity of glasses. Biomaterials, 23, 371-379. doi:10.1016/S0142-9612(01)00115-6

[30] Hench, L.L. and West, J.K. (1996) Biological applications 
of bioactive glasses. Life Chemistry Reports, 13, 187-241.

[31] Lin, K., Chang, J., Liu, Z., Zeng, Y. and Shen, R. (2009) Fabrication and characterization of $45 \mathrm{~S} 5$ bioglass reinforced macroporous calcium silicate bioceramics. Journal of the European Ceramic Society, 29, 2937-2943. doi:10.1016/j.jeurceramsoc.2009.04.025

[32] Zhong, J.P., La Torre G.P., et al. (1994) The kinetics of bioactive ceramics part VII: Binding of collagen to hydroxyapatite and bioactive glass. Bioceramics, 7, 61-66.

[33] Peitl, O., Zanotto, E.D. and Hench, L.L. (2001) Highly bioactive $\mathrm{P}_{2} \mathrm{O}_{5}-\mathrm{Na}_{2} \mathrm{O}-\mathrm{CaO}-\mathrm{SiO}_{2}$ glass-ceramics. Journal of Non-Crystalline Solids, 292, 115-126.
doi:10.1016/S0022-3093(01)00822-5

[34] Lefebvre, L., Chevalier, J., Gremillard, L., Zenati, R., Thollet, G., Bernache-Assolant, D. and Govin, A. (2007) Structural transformations of bioactive glass $45 \mathrm{~S} 5$ with thermal treatments. Acta Materialia, 55, 3305-3315. doi:10.1016/j.actamat.2007.01.029

[35] Mami, M., Lucas-Girot, A., Oudadesse, H., Dorbez-Sridi, R., Mezahi, F. and Dietrich, E. (2008) Investigation of the surface reactivity of a sol-gel derived glass in the ternary system $\mathrm{SiO}_{2}-\mathrm{CaO}-\mathrm{P}_{2} \mathrm{O}_{5}$. Applied Surface Science, 254, 7386-7393. doi:10.1016/j.apsusc.2008.05.340 